\title{
PENGARUH LEVERAGE DAN UKURAN PERUSAHAAN TERHADAP NILAI PERUSAHAAN DENGAN PROFITABILITAS SEBAGAI VARIABEL MEDIASI
}

\author{
Ni Putu Ira Kartika Dewi ${ }^{1}$ \\ Nyoman Abundanti ${ }^{2}$ \\ ${ }^{1,2}$ Fakultas Ekonomi dan Bisnis Universitas Udayana, Bali, Indonesia \\ email: kartikadewiira@yahoo.co.id
}

\begin{abstract}
ABSTRAK
Tujuan dari penelitian ini adalah untuk mengetahuipengaruh leverage dan ukuran perusahaan terhadap nilai perusahaan dengan profitabilitas sebagai variabel mediasi pada perusahaan industri barang konsumsi di Bursa Efek Indonesia.Populasi dalam penelitian ini adalah seluruh perusahaan industri barang konsumsi di Bursa Efek Indonesia yang berjumlah 46 perusahaan periode 2014-2017. Teknik penentuan sampel yang digunakan adalah purposivesampling, sehingga sampel akhir yang didapatkan adalah 21 perusahaan yang tergabung dalam industri barang konsumsi di Bursa Efek Indonesia periode 20142017.Teknik analisis data yang digunakan dalam penelitian ini adalah analisis jalur dan uji Sobel. Hasil analisis menunjukkanbahwa leverage berpengaruh negatif signifikan terhadap profitabilitasdan ukuran perusahaan berpengaruh positif signifikan terhadap profitabilitas. Leverage, ukuran perusahaandan profitabilitas berpengaruh positif signifikan terhadap nilai perusahaan. Profitabilitas secara signifikan memediasi pengaruh leverage terhadap nilai perusahaan serta profitabilitas secara signifikan memediasi pengaruh ukuran perusahaan terhadap nilai perusahaan.
\end{abstract}

Kata kunci : leverage, ukuran perusahaan, profitabilitas, nilai perusahaan

\begin{abstract}
The purpose of this study was to determine the effect of leverage and firm size on firm value with profitability as intervening variable on consumer goods industry in the Indonesian Stock Exchange. The population in this study are companies in the consumer goods industry Indonesian Stock Exchange amounted to 46 companies 2014-2017. Sampling technique used was purposive sampling, so that the final sample that is obtained is 21, a company incorporated in consumer goods industry in Indonesian Stock Exchange 2014-2017. Data analysis technique used in this research is path analysis and Sobel test. The result shows that leveragehas significant negative effect on profitability and firm size has significant positive effect on profitability. Leverage, firm size, and profitability have significant positive effect on firm value. Profitability mediates the effect of leverage on firm value significantly and profitability also mediates the effect of firm size on firm value significantly.

Keyword :leverage, firm size, profitability, firm value
\end{abstract}




\section{PENDAHULUAN}

Berdasarkan data Bursa Efek Indonesia (BEI) pada akhir bulan Juli 2018 total perusahaan yang telah mencatatkan sahamnya di pasar modal adalah sebanyak 594 perusahaan. Ini berarti bahwa semakin banyak perusahaan yang mendaftar semakin tinggi pula persaingan bagi para pengusaha di Indonesia. Persaingan tersebut membuat setiap perusahaan semakinmeningkatkan kinerja agar tujuan perusahaannya dapat tetap tercapai (Rudangga dan Sudiartha, 2016). Suatu perusahaan akan selalu berusaha untuk mencapai tujuan perusahaannya.Adapun tujuan perusahaan baik tujuan jangka panjang yaitu dengan meningkatkan nilai perusahaan dan mensejahterakan pemegang saham, maupun tujuan jangka pendek yaitu dengan memaksimalkan laba perusahaan. Perusahaan yang sudah go publicmenarik perhatian investor cenderung dengan cara meningkatkan nilai perusahaan (Pramana dan Mustanda, 2016). Nilai perusahaan adalah harga yang bersedia dibayar oleh calon pembeli apabila perusahaan dijual. Semakin tinggi nilai perusahaan, semakin besar kemakmuran yang akan diterima oleh pemilik perusahaan. Bagi perusahaan yang menerbitkan saham di pasar modal, harga saham yang diperjual-belikan di bursa merupakan indikator nilai perusahaan (Wiagustini, 2014: 9).

Terdapat banyak faktor yang mempengaruhi nilai suatu perusahaan. Leverage adalah salah satu faktor yang mempengaruhi nilai perusahaan. Solvabilitas atau leverage adalah mengukur sejauh mana perusahaan dibiayai dengan hutang (Wiagustini, 2014:85).Perusahaan dapat menggunakan leverage untuk memperoleh modal guna mendapatkan keuntungan yang lebih 
Ni Putu Ira Kartika Dewi, Pengaruh Levarge dan ...

tinggi(Suwardika dan Mustanda, 2017). Adanya perlindungan pajak membuat pengelolaan leverage sangatlah penting karena tingginya penggunaan leverage dapat meningkatkan nilai perusahaan (Setiadewi dan Purbawangsa, 2015). Leverage secara signifikan berpengaruh positif terhadap nilai perusahaan, hal ini sesuai dengan hasil penelitian yang dilakukan oleh Suwardika dan Mustanda (2017), Pratama dan Wiksuana (2016), serta Cheng dan Tzeng (2011). Hasil yang berlawanan didapatkan oleh Rahmadani dan Rahayu(2017) memperoleh hasil bahwa leverage mempunyai pengaruh yang negatif signifikan terhadap nilai perusahaan, namun penelitian yang dilakukan oleh Cherytaet al. (2017) menemukan hasil bahwa secara signifikan leverage tidak berpengaruh terhadap nilai perusahaan.

Nilai perusahaandapat dipengaruhi oleh ukuran perusahaan. Ukuran perusahaan mencakup besar kecilnya sebuah perusahaan yang diperlihatkan oleh aset, jumlah penjualan, rata-rata total penjualan dan total aset rata-rata (Dewi dan Badjra, 2017). Perusahaan besar secara umum akan mengungkapkan informasi yang lebih luas karena perusahaan besar memiliki banyak investor.Tingkat kemudahan perusahaan memperoleh dana dari pasar modal dapat ditentukan daribesar kecilnya ukuran perusahaan (Setiawati dan Lim, 2018). Kemudahan tersebut merupakan sebuah informasi yang menguntungkan bagi investor dalam pengambilan keputusan investasi dan nantinya akan mempengaruhi nilai perusahaan pada waktu yang akan datang (Nurhayati,2013).Novari dan Lestari (2016), Putu et al. (2014),serta Rizqia et al. (2013) memperoleh hasil bahwa ukuran perusahaan berpengaruh positif signifikan terhadap nilai perusahaan. Hasil 
yang bertentangan ditemukan oleh Setiadharma dan Machali (2017),Farooq danMasood (2016), sertaWinarto (2015)yang memperoleh hasil bahwa ukuran perusahaan secara signifikan tidak berpengaruh terhadap nilai perusahaan.

Profitabilitas menunjukkan kemampuan perusahaan memperoleh laba atau ukuran efektivitas pengelolaan manajemen perusahaan. Kemampuan memperoleh laba bisa diukur dari modal sendiri maupun dari seluruh dana yang diinvestasikan ke dalam perusahaan (Wiagustini, 2014:86).Peningkatan laba akan memberikan sinyal positif kepada investor bahwa perusahaan tersebut menguntungkan dan diharapkan mampu untuk memberikan kesejahteraan kepada pemegang saham melalui pengembalian saham yang tinggi (Pramana dan Mustanda, 2016). Penelitian yang dilakukan oleh Andawasatyaet al. (2017),Sucuahi dan Cambarihan (2016), Sabrin et al. (2016), Ulum (2015), Setiadewi dan Purbawangsa (2015), Hermuningsih (2013), serta Chen dan Chen (2011) menemukan bahwa profitabilitas berpengaruh positif signifikan terhadap nilai perusahaan.

Ada beberapa faktor yang mempengaruhi profitabilitas, salah satunya adalah leverage. Penambahan hutang dapat meningkatkan kemampuan perusahaan untuk memperoleh laba, karena dana yang tersedia untuk operasional perusahaan menjadi lebih besar. Hal tersebut menunjukkan bahwa leverage memiliki pengaruh terhadap profitabilitas, selama laba yang dihasilkan perusahaan masih lebih besar dari biaya bunga(Ardiansyah, 2017). Hasil penelitan ini sejalan dengan hasil penelitian yang dilakukan oleh Kartikasari dan Merianti (2016),Pratama dan Wiksuana (2016),serta Nadeem et al. (2015) yang menemukan hasil serupa 
yaitu leverage berpengaruh positif dan signifikan terhadap profitabilitas. Berbeda dengan hasil penelitian yang dilakukan oleh Adyatmika (2017), Purnamasari (2017), serta Putra dan Badjra (2015) yang memperoleh hasilbahwaleverage memiliki pengaruh negatif signifikan terhadap profitabilitas.

Profitabilitas juga dipengaruhi oleh faktor ukuran perusahaan. Ukuran perusahaan dapat dilihat dari total aset perusahaan. Semakin besar ukuran perusahaan, maka semakin besar probabilitas untuk melakukan peningkatan laba (Ambarwati dkk., 2015). Perusahaan dengan aset yang besarberpotensi untuk menghasilkan laba yang lebih baik karenadari adanya aset tersebut dapat meningkatkan kapasitas produksi perusahaan (Purnamasari dan Fitria, 2015). Pratama dan Wiksuana (2016) memperoleh hasil bahwa ukuran perusahaan berpengaruh positif signifikan terhadap profitabilitas. Berbeda dengan hasil penelitian yang dilakukan oleh Setiadewi dan Purbawangsa (2015) yang memperoleh hasil bahwa ukuran perusahaan berpengaruh tidak signifikan terhadap profitabilitas.

Berdasarkan hasil penelitian sebelumnya masih menunjukkan adanya hasil yang tidak konsisten terkait dengan pengaruh leverage dan ukuran perusahaan terhadap nilai perusahaan, sehingga diindikasikan adanya variabel lain yang mempengaruhi hubungan diantara kedua variabel tersebut terhadap nilai perusahaan. Dalam penelitian ini profitabilitas digunakan sebagai variabel mediasi karena leverage, ukuran perusahaan, dan profitabilitas berpengaruh terhadap nilai perusahaan dan sekaligus leverage dan ukuran perusahaan berpengaruh terhadap profitabilitas. 
Penelitian ini dilakukan pada perusahaan industri barang konsumsi. Perusahaan industri barang konsumsi merupakan industri yang menarik dan memiliki prospek yang baik karena produk barang konsumsi merupakan kebutuhan primer yang selalu dibutuhkan oleh masyarakat. Perusahaan industri barang konsumsi merupakan salah satu perusahaan yang cenderung stabil. Hal ini disebabkan karena sektor industri barang konsumsi secara langsung berkaitan dengan seluruh lapisan masyarakat baik untuk kalangan bawah, kalangan menengah maupun kalangan atas. Pada awal tahun 2017, sektor industri barang konsumsi di Bursa Efek Indonesia (BEI) berhasil mencatat pertumbuhan yang cukup tinggi. Sektor industri barang konsumsi berhasil mencatat pertumbuhan sebesar 21,98 persen secara year to date(www.investasi.kontan.co.id). Berdasarkan Analis PT Mirae Aset Sekuritas Indonesia menuliskan, saham sektor konsumer akan meningkat seiring dengan bertumbuhnya selera belanja masyarakat. Salah satu faktor pendorong belanja ialah proyeksi perbaikan Produk Domestik Bruto (PDB) menjadi 5,3 persen pada 2018 dan inflasi menuju 4,5 persen (www.bisnis.com).

Berdasarkan uraian latar belakang terdapat beberapa faktor yang mempengaruhi nilai perusahaan, namun hasil penelitian sebelumnya masih menunjukkan adanya research gap,maka penelitiingin meneliti lebih lanjut dengan tujuan untuk mengetahui pengaruh leverage dan ukuran perusahaan terhadap profitabilitas, untuk mengetahui pengaruh leverage, ukuran perusahaan dan profitabilitas terhadap nilai perusahaan, serta untuk mengetahui pengaruh 
leverage dan ukuran perusahaan terhadap nilai perusahaan dengan profitabilitas sebagai variabel mediasi.

Menurut Pratama dan Wiksuana (2016) leverage berpengaruh positif dan signifikan terhadap profitabilitas. Semakin tinggi pendanaan yang diperoleh dari hutang yang digunakan suatu perusahaan, semakin tinggi pula efektivitas perusahaan tersebut menghasilkan laba. Hal tersebut didukung oleh beberapa peniliti seperti Kartikasari danMerianti (2016) serta Nadeem et al. (2015) yang menemukan hasil bahwa leverage berpengaruh positif signifikan terhadap profitabilitas.

$\mathrm{H}_{1}$ : Leverage berpengaruh positif signifikan terhadap profitabilitas

Ukuran perusahaan dapat dilihat dari total aset perusahaan (Daniel dan Panji, 2017).Menurut Ambarwati dkk. (2015) semakin besar ukuran perusahaan, maka semakin besar probabilitas untuk melakukan peningkatan laba. Hal tersebut didukung oleh beberapa peniliti seperti Pratama dan Wiksuana (2016) serta Purnamasari dan Fitria (2015) yang menemukan hasil bahwa ukuran perusahaan berpengaruh positif signifikan terhadap profitabilitas.

$\mathrm{H}_{2}$ : Ukuran perusahaan berpengaruh positif signifikan terhadap profitabilitas

Dalam keadaan ada pajak, Modigliani dan Miller berpendapat bahwa nilai perusahaan bagi perusahaan yang menggunakan utang akan lebih besar daripada nilai perusahaan yang tidak menggunakan utang. Pada umumnya bunga yang dibayarkan bisa dipergunakan untuk mengurangi penghasilan yang dikenakan pajak (Husnan, 2014:306).Badruddien dkk. (2017), Suwardika dan Mustanda(2017), Pratama dan Wiksuana (2016), serta Cheng dan Tzeng (2011) 
menemukan bahwa leverage berpengaruh positif signifikan terhadap nilai perusahaan.

$\mathrm{H}_{3}$ : Leverage berpengaruh positif signifikan terhadap nilai perusahaan

Ukuran perusahaan adalah besar kecilnya suatu perusahaan yang dapat dilihat dari besarnya ekuitas, penjualan maupun total aktiva perusahaan. Bagi perusahaan yangmemiliki total aset besar, pihak manajemen perusahaannya akan lebih mudah mempergunakan aset yang ada untuk meningkatkan nilai perusahaan (Prasetia dkk., 2014). Pramana dan Mustanda (2016), Arindita dan Sampurno (2015), Prasetia dkk. (2014), Putu et al. (2014), serta Rizqia et al. (2013) menyatakan bahwa ukuran perusahaan berpengaruh positif signifikan terhadap nilai perusahaan.

$\mathrm{H}_{4}$ : Ukuran perusahaan berpengaruh positif signifikan terhadap nilai perusahaan

Profitabilitas suatu perusahaan yang tinggi akan menggambarkansemakin tinggi pula efisiensi perusahaan tersebut, sehingga terlihat bahwa kinerja perusahaan baik. Profitabilitas yang tinggi dapat meningkatkan nilai perusahaan (Suwardika dan Mustanda, 2017). Penelitian dari Musabbihan dan Purnawati (2018), Andawasatyaet al. (2017), Sucuahi dan Cambarihan (2016), Sudiani dan Darmayanti (2016), Sabrin et al. (2016), Ulum (2015), Setiadewi dan Purbawangsa (2015), Hermuningsih (2013), serta Chendan Chen (2011) menemukan bahwa profitabilitas berpengaruh positif signifikan terhadap nilai perusahaan.

$\mathrm{H}_{5}$ : Profitabilitas berpengaruh positif signifikan terhadap nilai perusahaan 
Leverage memiliki hubungan positif dan signifikan terhadap profitabilitas (Febria, 2013). Profitabilitas memiliki pengaruh positif dan signifikan terhadap nilai perusahaan (Dewi dan Badjra, 2017). Profitabilitas diharapkan mampu menjadi variabel mediasi antara leverageterhadap nilai perusahaan. Astutiningrum (2017) memperoleh hasil bahwa profitabilitas mampu memediasi pengaruh leverage terhadap nilai perusahaan.

$\mathrm{H}_{6}$ : Profitabilitas mampu memediasi pengaruh leverage terhadap nilai perusahaan Ukuran perusahaan berpengaruh positif dan signifikan terhadap profitabilitas. Perusahaan yang memiliki ukuran besar mempunyai pengaruh terhadap peningkatan profitabilitas (Hansen dan Juniarti, 2014). Perusahaan yang mampu meningkatkan laba,mengindikasikan perusahaan tersebut memiliki kinerja yang baik sehingga dapat menciptakan tanggapan yang positif dari investor dan dapat meningkatkan harga saham dari perusahaan tersebut (Rudangga dan Sudiartha, 2016). Profitabilitas diharapkan mampu menjadi variabel mediasi antara ukuran perusahaan terhadap nilai perusahaan. Laksitaputri (2012) memperoleh hasil bahwa profitabilitas mampu memediasi pengaruh ukuran perusahaan terhadap nilai perusahaan.

$\mathrm{H}_{7}$ : Profitabilitas mampu memediasi pengaruh ukuran perusahaan terhadap nilai perusahaan

\section{METODE PENELITIAN}

Desain penelitian yang digunakan dalam penelitian ini merupakan desain asosiatif. Penelitian ini menggunakan pendekatan kuantitatif dengan bentuk asosiatif yaitu penelitian yang menyatakan hubungan dua variabel atau lebih. Obyek penelitian dalam penelitian ini adalah nilai perusahaan yang dipengaruhi 
oleh leverage dan ukuran perusahaan melalui profitabilitas pada perusahaan industri barang konsumsi di Bursa Efek Indonesia periode 2014-2017. Persamaan struktur I untuk variabel independen yang digunakan dalam penelitian ini adalah leverage $\left(\mathrm{X}_{1}\right)$ dan ukuran perusahaan $\left(\mathrm{X}_{2}\right)$ serta variabel dependen yang digunakan adalah profitabilitas $\left(\mathrm{Y}_{1}\right)$. Persamaan struktur II untuk variabel independen yang digunakan adalah leverage $\left(\mathrm{X}_{1}\right)$, ukuran perusahaan $\left(\mathrm{X}_{2}\right)$, dan profitabilitas $\left(\mathrm{Y}_{1}\right)$ serta variabel dependen yang digunakan adalah nilai perusahaan $\left(\mathrm{Y}_{2}\right)$. Pengukuran untuk masing-masing variabel yang ada dalam penelitian ini adalah sebagai berikut :

Nilai perusahaan diproksikan dengan Price to Book Value $(P B V)$, yaitu dengan rumus (Dewi dan Candradewi , 2018):

$$
P B V=\frac{H \quad n a}{N}
$$

Leverage dapat diukur dengan Debt to Equity Ratio (DER) yang dapat dihitung dengan rumus (Sartono, 2014: 121):

$$
\text { Debt to Equity Ratio }=\frac{T}{T} \times 100 \%
$$

Ukuran perusahaan (Size) dihitung dengan rumus sebagai berikut (Novari dan Lestari, 2016):

$$
\text { Size }=\text { Total Aset. }
$$

Profitabilitas sebagai variabel intervening diukur menggunakan Return on Assets (ROA) yang dapat dihitung dengan rumus (Wiagustini, 2014:94):

$$
R O A=\frac{L}{T} \quad n=100 \%
$$

Seluruh perusahaan industri barang konsumsiyang terdaftar di Bursa Efek Indonesia periode 2014-2017 yang berjumlah 46 perusahaan merupakan populasi 
dalam penelitian ini.Teknik penentuan sampel yang digunakan dalam penelitian ini adalah dengan metode purposive sampling. Berdasarkan kriteria tertentu dari 46 perusahaan diperoleh sampel sebanyak 21 perusahaan dengan empat tahun pengamatan sehingga diperoleh jumlah pengamatan sebesar 84 .

Penelitian ini menggunakan metode pengumpulan data berupa metode observasi non partisipan. Jenis data yang digunakan adalah data kuantitatif. Sumber data yang digunakan adalah jenis data sekunder. Data sekunder dari penelitian ini diperoleh dari ringkasan kerja perusahaan industri barang konsumsi pada Bursa Efek Indonesia periode 2014-2017 yang dapat diakses melalui website resmi Bursa Efek Indonesia yaitu www.idx.co.id. Teknik analisis data yang digunakan adalah analisis jalur dan uji Sobel. Tujuan utama dari analisis jalur adalah untuk memprediksi kebermaknaan hubungan suatu variabel dengan variabel lainnya serta adanya pengaruh tidak langsung (Utama, 2014:168).

\section{HASIL DAN PEMBAHASAN}

Tabel 1.

Hasil Analisis Statistik Deskriptif

\begin{tabular}{lrrrrr}
\hline & N & Minimum & Maximum & \multicolumn{1}{c}{ Mean } & \multicolumn{1}{c}{$\begin{array}{c}\text { Std. } \\
\text { Deviation }\end{array}$} \\
\hline N Valid & 84 & & & & \\
DER $\left(\mathrm{X}_{1}\right)$ & 84 & 7,00 & 195,0 & 70,4524 & 46,08227 \\
Size $\left(\mathrm{X}_{2}\right)$ & 84 & 159,564 & $91,831,526$ & $10,223,854$ & $19,808,670$ \\
ROA $\left(\mathrm{Y}_{1}\right)$ & 84 & 0,65 & 35,87 & 10,8106 & 7,62384 \\
$P B V\left(\mathrm{Y}_{2}\right)$ & 84 & 0,26 & 27,35 & 4,0677 & 4,00125 \\
\hline Sumber: Data sekunder diolah, 2018 & & & &
\end{tabular}

Berdasarkan Tabel 1 diketahui bahwa variabel leverage (DER) nilai rataratanya sebesar 70,4524 persen. Nilai standar deviasi variabel leverage $(D E R)$ sebesar 46,08227 persen. Nilai minimum sebesar 7,00 persen dimiliki oleh Industri Jamu dan Farmasi Sido Muncul Tbk. pada tahun 2014, sedangkan nilai 
maksimum sebesar 195 persen dimiliki oleh Budi Starch \& Sweetener Tbk. pada tahun 2015.

Variabel ukuran perusahaan nilai rata-ratanya sebesar 10,223,845 juta rupiah. Nilai standar deviasi variabel ukuran perusahaan sebesar 19,808,670 juta rupiah. Nilai minimum sebesar 159,564 juta rupiah dimiliki oleh Pyridam Farma Tbk. pada tahun 2017, sedangkan nilai maksimum sebesar 91,831,526 juta rupiah dimiliki oleh Indofood Sukses Makmur Tbk. pada tahun 2015.

Variabel profitabilitas (ROA) nilai rata-ratanya sebesar 10,8106 persen, Nilai standar deviasi variabel profitabilitas $(R O A)$ sebesar 7,62384 persen. Nilai minimum sebesar 0,65 persen dimiliki oleh Budi Starch \& Sweetener Tbk. pada tahun 2015, sedangkan nilai maksimum sebesar 35,87 persen dimiliki oleh Hanjaya Mandala Sampoerna Tbk. pada tahun 2014.

Variabel nilai perusahaan $(P B V)$ memiliki nilai rata-rata sebesar 4,0677 kali. Nilai standar deviasi variabel nilai perusahaan $(P B V)$ sebesar 4,00125 kali. Nilai minimum sebesar 0,26 kali dimiliki oleh Budi Starch \& Sweetener Tbk. pada tahun 2015, sedangkan nilai maksimum sebesar 27,35 kali dimiliki oleh Hanjaya Mandala Sampoerna Tbk. pada tahun 2014.

Analisis jalur (path analysis) menggunakan dua tahap uji asumsi klasik. Substruktur I pada $\left(\mathrm{Y}_{1}\right)$ untuk menguji variabel bebas leverage $(D E R)$ dan ukuran perusahaan terhadap variabel profitabilitas $(R O A)$. Substruktur II pada $\left(\mathrm{Y}_{2}\right)$ untuk menguji variabel bebasleverage $(D E R)$, ukuran perusahaan, dan profitabilitas $(R O A)$ terhadap variabel nilai perusahaan $(P B V)$. 
Tabel 2.

Uji Normalitas Substruktur I

\begin{tabular}{|c|c|c|}
\hline & & $\begin{array}{c}\text { Unstandardized } \\
\text { Residual }\end{array}$ \\
\hline $\mathrm{N}$ & & 84 \\
\hline \multirow[t]{2}{*}{ Normal Parameters ${ }^{\mathrm{a}, \mathrm{b}}$} & Mean & 0,0000000 \\
\hline & Std.Deviation & 0,60101132 \\
\hline Most Extreme & Absolute & 0,069 \\
\hline \multirow{2}{*}{ Differences } & Positive & 0,044 \\
\hline & Negative & - 0,069 \\
\hline \multicolumn{2}{|c|}{ Kolmogorov-Smirnov Z } & 0,635 \\
\hline \multicolumn{2}{|l|}{ Asymp. Sig. (2-tailed) } & 0,815 \\
\hline
\end{tabular}

Sumber: Data sekunder diolah,2018

Berdasarkan Tabel 2 diketahui bahwa koefisien Asymp.Sig (2-tailed) sebesar 0,815 dan tingkat signifikansi yang digunakan adalah $5 \%(0,05)$. Hasil ini menunjukkan bahwa data yang digunakan pada substruktur I adalah berdistribusi normal karena 0,815 lebih besar dari 0,05.

Tabel 3.

Uji Normalitas Substruktur II

\begin{tabular}{llr}
\hline & & \multicolumn{2}{c}{$\begin{array}{c}\text { Unstandardized } \\
\text { Residual }\end{array}$} \\
\hline $\mathrm{N}$ & & 84 \\
Normal Parameters & a,b & Mean \\
& Std.Deviation & 0,0000000 \\
Most Extreme & Absolute & 0,54214480 \\
Differences & Positive & 0,080 \\
& Negative & 0,068 \\
Kolmogorov-Smirnov Z & & $-0,080$ \\
Asymp. Sig. (2-tailed) & & 0,729 \\
\hline
\end{tabular}

Sumber:Data sekunder diolah,2018

Berdasarkan Tabel 3 diketahui bahwa koefisien Asymp.Sig. (2-tailed) sebesar 0,662 dan tingkat signifikansi yang digunakan adalah 5\% $(0,05)$. Hasil ini menunjukkan bahwa data yang digunakan pada substruktur II adalah berdistribusi normal karena 0,662 lebih besar dari 0,05.

Berdasarkan Tabel 4 diketahui bahwa variabel leverage $(D E R)$ dan variabel ukuran perusahaan (Size) memiliki nilai tolerance sebesar 0,996 yang lebih besar dari 0,10. Variabel leverage (DER) dan variabel ukuran perusahaan (Size) 
memiliki VIF sebesar 1,006 yang lebih kecil dari 10, maka dapat disimpulkan bahwa data yang digunakan pada substruktur I tidak ada multikolinearitas.

Tabel 4.

Uji Multikolinearitas Substruktur I

\begin{tabular}{llcc}
\hline & & \multicolumn{2}{c}{ Collinearity Statistics } \\
\cline { 3 - 4 } Model & & Tolerance & VIF \\
\hline 1 & $\operatorname{DER}\left(\mathrm{X}_{1}\right)$ & 0,996 & 1,006 \\
& $\operatorname{Size}\left(\mathrm{X}_{2}\right)$ & 0,996 & 1,006 \\
\hline
\end{tabular}

Sumber: Data sekunder diolah,2018

Tabel 5.

Uji Multikolinearitas Substruktur II

\begin{tabular}{llcr}
\hline & & \multicolumn{3}{c}{ Collinearity Statistics } \\
\cline { 2 - 3 } Model & Tolerance & VIF \\
\hline 1 & 0,585 & 1,711 \\
Size $\left(\mathrm{X}_{2}\right)$ & 0,898 & 1,114 \\
ROA $\left(\mathrm{Y}_{1}\right)$ & 0,540 & 1,852 \\
\hline
\end{tabular}

Sumber: Data sekunder diolah, 2018

Berdasarkan Tabel 5 diketahui bahwa variabel leverage (DER) memiliki nilai tolerance sebesar 0,585 , variabel ukuran perusahaan memiliki nilai tolerance sebesar 0,898dan variabel profitabilitas $(R O A)$ memiliki nilai tolerance sebesar 0,540yang lebih besar dari 0,10. Pada variabel leverage (DER) memiliki VIF sebesar 1,711, variabel ukuran perusahaan (Size) memiliki VIF sebesar 1,114 dan variabel profitabilitas $(R O A)$ memiliki VIF sebesar 1,852 yang lebih kecil dari 10, maka dapat disimpulkan bahwa data yang digunakan pada substruktur II tidak ada multikolinearitas.

Berdasarkan Tabel 6 diketahui bahwa nilai signifikansi dari variabel leverage $(D E R)$ sebesar 0,122 dan variabel ukuran perusahaan (Size) sebesar 0,167 yang menunjukkan angka lebih besar dari 0,05 (5\%), maka dapat disimpulkan bahwa data yang digunakan pada substruktur I tidak terjadi heteroskedastisitas. 
Tabel 6.

Uji Heteroskedastisitas Substruktur I

\begin{tabular}{|c|c|c|c|c|c|}
\hline \multirow[t]{2}{*}{ Model } & \multicolumn{2}{|c|}{$\begin{array}{l}\text { Unstandardized } \\
\text { Coefficients }\end{array}$} & \multirow{2}{*}{$\begin{array}{c}\begin{array}{c}\text { Standardized } \\
\text { Coefficients }\end{array} \\
\text { Beta } \\
\end{array}$} & \multirow[b]{2}{*}{$\mathbf{T}$} & \multirow[b]{2}{*}{ Sig. } \\
\hline & B & Std. Error & & & \\
\hline (Constant) & 1,674 & 1,137 & & 1,471 & 0,145 \\
\hline$D E R\left(\mathrm{X}_{1}\right)$ & 0,082 & 0,052 & 0,169 & 1,563 & 0,122 \\
\hline $\operatorname{Size}\left(\mathrm{X}_{2}\right)$ & $-0,570$ & 0,409 & $-0,151$ & $-1,394$ & 0,167 \\
\hline
\end{tabular}

Sumber: Data sekunder diolah, 2018

Tabel 7.

Uji Heteroskedastisitas Substruktur II

\begin{tabular}{|c|c|c|c|c|c|}
\hline \multirow[t]{2}{*}{ Model } & \multicolumn{2}{|c|}{$\begin{array}{l}\text { Unstandardized } \\
\text { Coefficients }\end{array}$} & \multirow{2}{*}{$\begin{array}{c}\begin{array}{c}\text { Standardized } \\
\text { Coefficients }\end{array} \\
\text { Beta } \\
\end{array}$} & \multirow[b]{2}{*}{$\mathbf{t}$} & \multirow[b]{2}{*}{ Sig. } \\
\hline & B & Std. Error & & & \\
\hline (Constant) & $-1,465$ & 1,049 & & $-1,397$ & 0,166 \\
\hline$D E R\left(\mathrm{X}_{1}\right)$ & 0,122 & 0,063 & 0,270 & 1,945 & 0,055 \\
\hline $\operatorname{Size}\left(\mathrm{X}_{2}\right)$ & 0,520 & 0,397 & 0,147 & 1,308 & 0,195 \\
\hline$R O A\left(\mathrm{Y}_{1}\right)$ & $-0,010$ & 0,063 & $-0,022$ & $-0,152$ & 0,880 \\
\hline
\end{tabular}

Sumber: Data sekunder diolah, 2018

Berdasarkan Tabel 7 diketahui bahwa nilai signifikansi dari variabel leverage $(D E R)$ sebesar 0,055, variabel ukuran perusahaan (Size) sebesar 0,195 dan variabel profitabilitas $(R O A)$ sebesar $\quad 0,880$ yang menunjukkan angka lebih besar dari 0,05 (5\%), maka dapat disimpulkan bahwa data yang digunakan pada substruktur II tidak terjadi heteroskedastisitas.

Tabel 8.

Uji Autokorelasi Substruktur I

\begin{tabular}{cccccc}
\hline Model & $\mathbf{R}$ & R square & $\begin{array}{c}\text { Adjusted } \\
\text { R square }\end{array}$ & $\begin{array}{c}\text { Std. Error of } \\
\text { The Estimate }\end{array}$ & $\begin{array}{c}\text { Durbin- } \\
\text { Waston }\end{array}$ \\
\hline 1 & $0,678^{\mathrm{a}}$ & 0,460 & 0,447 & 0,60839 & 1,744 \\
\hline
\end{tabular}

Sumber: Data sekunder diolah, 2018

Berdasarkan Tabel 8 diketahui bahwa nilai Durbin-Watson-nya sebesar 1,744. Berdasarkan nilai signifikansi 5\% (0,05), untuk jumlah data sebanyak 84 dan jumlah variabel eksogen $(k=2)$, maka $d_{L}=1,60$ dan $d_{u}=1,70$. Nilai DurbinWatson substruktur I sebesar 1,744 lebih besar dari nilai $\mathrm{d}_{\mathrm{u}}=1,70$ dan lebih kecil dari nilai $4-d_{u}=2,30$, sehingga dapat disimpulkan tidak ada autokorelasi. 
Tabel 9.

Uji Autokorelasi Substruktur II

\begin{tabular}{lccccc}
\hline Model & $\mathbf{R}$ & $\begin{array}{c}\mathbf{R} \\
\text { square }\end{array}$ & $\begin{array}{c}\text { Adjusted } \\
\text { R square }\end{array}$ & $\begin{array}{c}\text { Std. Error of } \\
\text { The Estimate }\end{array}$ & $\begin{array}{c}\text { Durbin- } \\
\text { Waston }\end{array}$ \\
\hline 1 & $0,803^{\mathrm{a}}$ & 0,645 & 0,632 & 0,55222 & 2,136 \\
\hline \multicolumn{2}{l}{ Sumber: Data sekunder diolah, 2018} & & &
\end{tabular}

Berdasarkan Tabel 9 diketahui bahwa nilai Durbin-Watson-nya sebesar 2,136. Berdasarkan nilai signifikansi 5\% (0,05), untuk jumlah data sebanyak 84 dan jumlah variabel eksogen $(k=3)$, maka $d_{L}=1,57$ dan $d_{u}=1,72$. Nilai DurbinWatson substruktur II sebesar 2,136 lebih besar dari nilai $\mathrm{d}_{\mathrm{u}}=1,72$ dan lebih kecil dari nilai 4- $\mathrm{d}_{\mathrm{u}}=2,28$, sehingga dapat disimpulkan tidak ada autokorelasi.

Analisis jalur atau path analysis digunakan untuk menganalisis hubungan antar variabel bebas (eksogen) dengan variabel terikat (endogen) dengan tujuan untuk mengetahui pengaruh langsung atau tidak langsungnya. Langkah-langkah menguji analisis jalur adalah sebagai berikut (Riduwan dan Kuncoro (2011: 128):

1) Merumuskan persamaan struktural

Struktur I :

$$
\begin{aligned}
& \mathrm{Y}_{1}=\beta_{1} \mathrm{X}_{1}+\beta_{2} \mathrm{X}_{2}+\mathrm{e}_{1} \\
& Y_{1}=-0,618 X_{1}+0,244 X_{2}+0,734 e_{1} \\
& \mathrm{e}_{1}=\sqrt{1-\mathrm{R}^{2} \ldots}
\end{aligned}
$$

$\mathrm{e}_{1}=\sqrt{1-\mathrm{R}^{2}=} \sqrt{1-0,460}=0,734$

Struktural II

$$
\begin{aligned}
& \mathrm{Y}_{2}=\beta_{3} \mathrm{X}_{1}+\beta_{4} \mathrm{X}_{2}+\beta_{5} \mathrm{Y}_{1}+\mathrm{e}_{2} \ldots \ldots \ldots \ldots \ldots \ldots \ldots \ldots \\
& \mathrm{Y}_{2}=0,222 \mathrm{X}_{1}+0,152 \mathrm{X}_{2}+0,863 \mathrm{Y}_{1}+0,595 \mathrm{e}_{2} \\
& \mathrm{e}_{2}=\sqrt{1-\mathrm{R}^{2}}=\sqrt{1-0,645}=0,595
\end{aligned}
$$


2) Diagram jalur

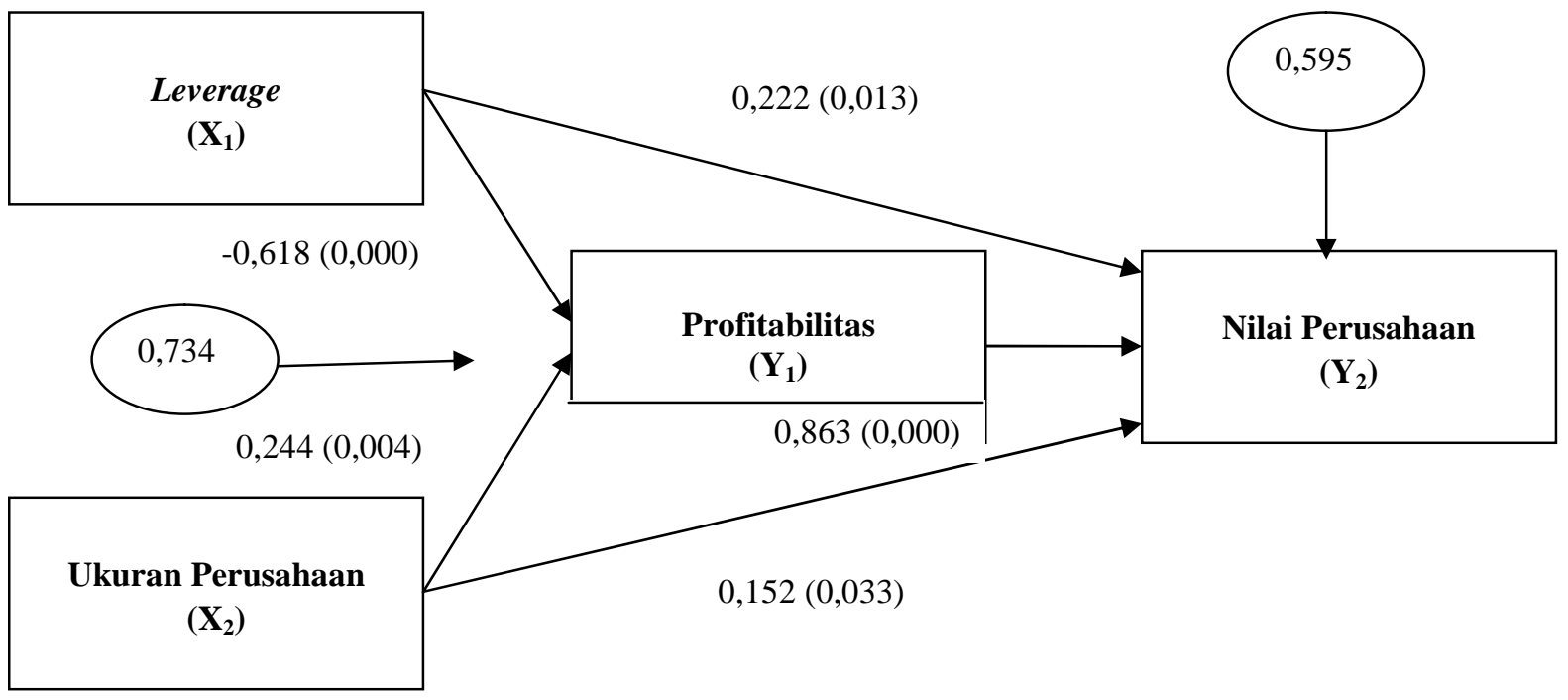

Gambar 1.Diagram Jalur Hubungan Leverage, Ukuran Perusahaan, Profitabilitas dan Nilai perusahaan

Sumber: Data sekunder diolah, 2018

3) Uji F

Tabel 10.

Hasil Uji F Substruktur I

\begin{tabular}{llrrrrr}
\hline & Model & $\begin{array}{c}\text { Sum of } \\
\text { Squares }\end{array}$ & df & \multicolumn{1}{c}{$\begin{array}{c}\text { Mean } \\
\text { Square }\end{array}$} & F & Sig. \\
\hline 1 & Regression & 25,544 & 2 & 12,772 & 34,507 & $0,000^{\mathrm{a}}$ \\
& Residual & 29,981 & 81 & 0,370 & & \\
& Total & 55,525 & 83 & & & \\
\hline
\end{tabular}

Sumber: Data sekunder diolah, 2018

Tabel 11.

Hasil Uji FSubstruktur II

\begin{tabular}{llrrrrr}
\hline & Model & $\begin{array}{c}\text { Sum of } \\
\text { Squares }\end{array}$ & df & \multicolumn{1}{c}{$\begin{array}{c}\text { Mean } \\
\text { Square }\end{array}$} & F & Sig. \\
\hline 1 & Regression & 44,404 & 3 & 14,801 & 48,538 & $0,000^{\text {a }}$ \\
& Residual & 24,395 & 80 & 0,305 & & \\
& Total & 68,799 & 83 & & & \\
\hline
\end{tabular}

Sumber: Data sekunder diolah, 2018

Berdasarkan Tabel10 dan Tabel11diketahui bahwa hasil uji $\mathrm{F}$ yang dilakukan menunjukkan nilai $\mathrm{F}$ sebesar 34,507 dan 48,538 dengan tingkat signifikansi $0,000<0,05$. Hal tersebut menunjukkan bahwa $D E R$ dan Size secara 
signifikanberpengaruh terhadap ROA sertaDER, Size, ROA secara signifikanberpengaruh terhadap $P B V$ sehingga dapat disimpulkan bahwa model penelitian ini dikatakan layak untuk diteliti.

4) Pengujian koefisien jalur secara parsial

Tabel 12.

Hasil Uji Parsial Substruktur I

\begin{tabular}{|c|c|c|c|c|c|}
\hline \multirow[t]{2}{*}{ Model } & \multicolumn{2}{|c|}{$\begin{array}{l}\text { Unstandardized } \\
\text { Coefficients }\end{array}$} & \multirow{2}{*}{$\begin{array}{c}\begin{array}{c}\text { Standardized } \\
\text { Coefficients }\end{array} \\
\text { Beta }\end{array}$} & \multirow{2}{*}{$\mathbf{T}$} & \multirow{2}{*}{ Sig. } \\
\hline & B & Std. Error & & & \\
\hline $1 \quad$ (Constant) & $-0,666$ & 1,838 & & $-0,362$ & 0,718 \\
\hline $\operatorname{DER}\left(\mathrm{X}_{1}\right)$ & $-0,637$ & 0,084 & $-0,618$ & $-7,549$ & 0,000 \\
\hline $\operatorname{Size}\left(\mathrm{X}_{2}\right)$ & 1,970 & 0,661 & 0,244 & 2,979 & 0,004 \\
\hline
\end{tabular}

Berdasarkan Tabel 12 dapat diketahui bahwa nilai signifikansi DER sebesar 0,000 lebih kecil dari 0,05 . Hal ini menunjukkan bahwa terdapat pengaruh yang signifikan antara DER terhadap ROA. Pada Standardized Coefficients nilai beta sebesar -0,618 yang menunjukkan arah yang negatif, nilai tersebut menunjukkan bahwa jika DER meningkat maka ROAakan mengalami penurunan dan sebaliknya. Nilai signifikansi Size sebesar 0,004 lebih kecil dari 0,05. Hal ini menunjukkan bahwa terdapat pengaruh yang signifikan antara Size terhadap ROA. Pada Standardized Coefficients nilai beta sebesar 0,244 yang menunjukkan arah yang positif, nilai tersebut menunjukkan bahwa jika Size meningkat maka $R O A$ akan mengalami peningkatan dan sebaliknya.

Berdasarkan Tabel 13 dapat diketahui bahwa nilai signifikansi DER sebesar 0,013 lebih kecil dari 0,05. Hal ini menunjukkan bahwa terdapat pengaruh yang signifikan antara $D E R$ terhadap $P B V$. Pada Standardized Coefficients nilai beta sebesar 0,222 yang menunjukkan arah yang positif, nilai tersebut menunjukkan 
bahwa jika $D E R$ meningkat maka $P B V$ akan mengalami peningkatan juga dan sebaliknya. Nilai signifikansi Size sebesar 0,033 lebih kecil dari 0,05. Hal ini menunjukkan bahwa terdapat pengaruh yang signifikan antara Sizeterhadap $P B V$. Pada Standardized Coefficients nilai beta sebesar 2,169 yang menunjukkan arah yang positif, nilai tersebut menunjukkan bahwa jika Sizemeningkat maka $P B V$ akan mengalami peningkatan dan sebaliknya. Nilai signifikansiROA sebesar 0,000 lebih kecil dari 0,05. Hal ini menunjukkan bahwa terdapat pengaruh yang signifikan antara ROAterhadap $P B V$. Pada Standardized Coefficients nilai beta sebesar 9,527 yang menunjukkan arah yang positif, nilai tersebut menunjukkan bahwa jika $R O A$ meningkatmaka $P B V$ akan mengalami peningkatan dan sebaliknya.

Tabel 13.

Hasil Uji Parsial Substruktur II

\begin{tabular}{|c|c|c|c|c|c|}
\hline \multirow[t]{2}{*}{ Model } & \multicolumn{2}{|c|}{$\begin{array}{l}\text { Unstandardized } \\
\text { Coefficients }\end{array}$} & \multirow{2}{*}{$\begin{array}{c}\begin{array}{c}\text { Standardized } \\
\text { Coefficients }\end{array} \\
\text { Beta } \\
\end{array}$} & \multirow[b]{2}{*}{$\mathbf{T}$} & \multirow[b]{2}{*}{ Sig. } \\
\hline & B & Std. Error & & & \\
\hline $1 \quad$ (Constant) & $-5,713$ & 1,670 & & $-3,421$ & 0,001 \\
\hline $\operatorname{DER}\left(\mathrm{X}_{1}\right)$ & 0,255 & 0,100 & 0,222 & 2,545 & 0,013 \\
\hline $\operatorname{Size}\left(\mathrm{X}_{2}\right)$ & 1,371 & 0,632 & 0,152 & 2,169 & 0,033 \\
\hline$R O A\left(\mathrm{Y}_{1}\right)$ & 0,961 & 0,101 & 0,863 & 9,527 & 0,000 \\
\hline
\end{tabular}

Sumber: Data sekunder diolah, 2018

Pemeriksaan validitas model

$$
\begin{aligned}
& \mathrm{R}_{\mathrm{m}}^{2}=1-\left(\mathrm{e}_{1}{ }^{2}\right) \times\left(\mathrm{e}_{2}^{2}\right) \ldots \ldots \ldots \ldots . . . \\
& \mathrm{R}_{\mathrm{m}}^{2}=1-\left(0,734^{2}\right) \times\left(0,595^{2}\right) \\
& \mathrm{R}_{\mathrm{m}}^{2}=1-0,19 \\
& \mathrm{R}_{\mathrm{m}}^{2}=0,81
\end{aligned}
$$

Berdasarkan hasil perhitungankoefisien determinasi total $\left(\mathrm{R}_{\mathrm{m}}^{2}\right)$ menunjukkan bahwa variasi data yang dipengaruhi oleh model sebesar $81 \%$ artinya informasi 
yang terkandung di dalam data sebesar $81 \%$ dapat dijelaskan oleh model dan sisanya sebesar $19 \%$ dijelaskan oleh variabel lain di luar model.

5) Perhitungan pengaruh langsung, pengaruh tidak langsung, dan pengaruh total

Berdasarkan hasil analisis jalur, maka dapat dihitung pengaruh langsung, pengaruh tidak langsung, dan pengaruh total dari model yang telah dibuat adalah sebagai berikut:

Tabel 14.

Pengaruh Langsung, Pengaruh Tidak Langsung dan PengaruhTotal Variabel

\begin{tabular}{|c|c|c|c|}
\hline $\begin{array}{c}\text { Pengaruh } \\
\text { Variabel }\end{array}$ & $\begin{array}{l}\text { Pengaruh } \\
\text { Langsung }\end{array}$ & $\begin{array}{l}\text { Pengaruh Tidak } \\
\text { Langsung }\end{array}$ & $\begin{array}{c}\text { Pengaruh } \\
\text { Total }\end{array}$ \\
\hline DERRQA & $-0,618$ & - & - \\
\hline SizeROA & 0,244 & - & - \\
\hline$D E R P B \backslash \longrightarrow$ & 0,222 & $-0,533$ & $-0,311$ \\
\hline SizePBҢ & 0,152 & 0,210 & 0,362 \\
\hline$R O A P B \backslash \longrightarrow$ & 0,863 & - & - \\
\hline
\end{tabular}

Peran profitabilitas memediasi pengaruh leverage terhadap nilai perusahaan

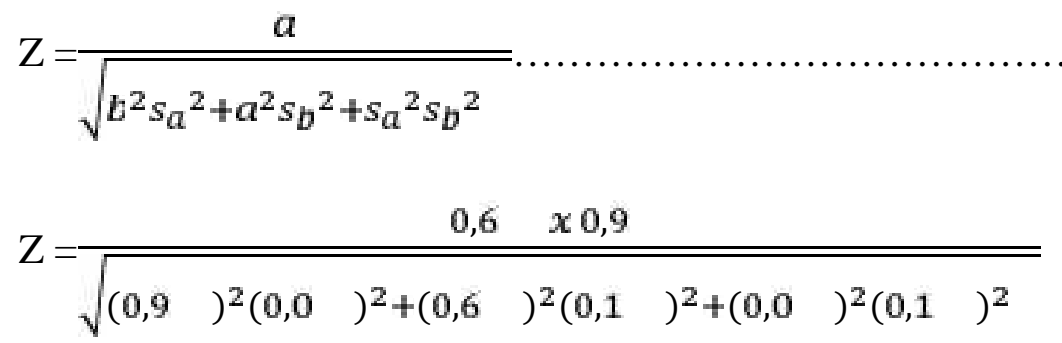

$$
\begin{aligned}
& Z=\frac{0,6}{\sqrt{0,0}} \\
& Z=5,90999
\end{aligned}
$$


Nilai Z sebesar 5,90999lebih besar dari 1,96 maka dapat dikatakan variabel intervening dinilai secara signifikan memediasi hubungan antara variabel leverage $\left(\mathrm{X}_{1}\right)$ dengan variabel nilai perusahaan $\left(\mathrm{Y}_{2}\right)$.

Peran profitabilitas memediasi pengaruh ukuran perusahaan terhadap nilai perusahaan

$$
\begin{aligned}
& Z=\frac{1,9 \quad x 0,9}{\sqrt{(0,9 \quad)^{2}(0,6 \quad)^{2}+(1,9 \quad)^{2}(0,1 \quad)^{2}+(0,6 \quad)^{2}(0,1 \quad)^{2}}} \\
& Z=\frac{1,8}{\sqrt{0,4}} \\
& Z=2,82989
\end{aligned}
$$

Nilai Z sebesar 2,82989 lebih besar dari 1,96 maka dapat dikatakan variabel intervening dinilai secara signifikan memediasi hubungan antara variabel ukuran perusahaan $\left(\mathrm{X}_{2}\right)$ dengan variabel nilai perusahaan $\left(\mathrm{Y}_{2}\right)$.

Berdasarkan hasil penelitian,leverage berpengaruh negatif dan signifikan terhadap profitabilitas sehingga hipotesis pertama ditolak. Pengaruh negatif dan signifikan tersebut menunjukkan bahwa semakin meningkatnya leverage perusahaan maka profitabilitas akan menurun. Hasil penelitian ini sejalan dengan penelitian Adiyatmika (2017), Purnamasari (2017),serta Putra dan Badjra (2015)yang menemukan bahwaleverage berpengaruh negatif signifikan terhadap profitabilitas.

Berdasarkan hasil penelitian,ukuran perusahaan berpengaruh positif dan signifikan terhadap profitabilitassehingga hipotesis kedua diterima. Pengaruh positif dan signifikan tersebut menunjukkan bahwa semakin meningkatnya ukuran 
perusahaan maka profitabilitas juga akan meningkat. Hasil penelitian ini sejalan dengan penelitian Pratama dan Wiksuana (2016) serta Purnamasari dan Fitria (2015) yang menemukan bahwa ukuran perusahaan berpengaruh positif signifikan terhadap profitabilitas.

Berdasarkan hasil penelitian,leverage berpengaruh positif dan signifikan terhadap nilai perusahaan sehingga hipotesis ketiga diterima. Pengaruh positif dan signifikan tersebut menunjukkan bahwa semakin meningkatnya leverage perusahaan maka nilai perusahaan juga akan meningkat. Hasil penelitian ini sejalan dengan penelitian Badruddien dkk. (2017), Suwardika dan Mustanda (2017), Pratama dan Wiksuana (2016), serta Cheng dan Tzeng (2011) yang menemukan bahwa leverage berpengaruh positif signifikan terhadap nilai perusahaan.

Berdasarkan hasil penelitian,ukuran perusahaan berpengaruh positif dan signifikan terhadap nilai perusahaansehingga hipotesis keempat diterima. Pengaruh positif dan signifikan tersebut menunjukkan bahwa semakin meningkatnya ukuran perusahaan maka nilai perusahaan juga akan meningkat. Hasil penelitian ini sejalan dengan penelitian Pramana dan Mustanda (2016), Novari dan Lestari (2016), Febriana dan Djumahir (2016), Prasetia dkk. (2014), Putu et al. (2014), serta Rizqia et al. (2013) yang menemukan bahwa ukuran perusahaan berpengaruh positif signifikan terhadap nilai perusahaan.

Berdasarkan hasil penelitian,profitabilitas berpengaruh positif dan signifikan terhadap nilai perusahaansehingga hipotesis kelima diterima. Pengaruh positif dan signifikan tersebut menunjukkan bahwa semakin meningkatnya profitabilitas 
Ni Putu Ira Kartika Dewi, Pengaruh Levarge dan ...

maka nilai perusahaan juga akan meningkat. Hasil penelitian ini sejalan dengan penelitian Musabbihan dan Purnawati (2018), Andawasatyaet al. (2017), Suwardika dan Mustanda (2017), Sucuahi dan Cambarihan (2016), Sabrin et al. (2016), Ulum (2015), Setiadewi dan Purbawangsa (2015), Hermuningsih (2013), serta Chen dan Chen (2011) yang menemukan bahwa profitabilitas berpengaruh positif signifikan terhadap nilai perusahaan.

Hasil dalam penelitian ini menunjukkan bahwa profitabilitas secara signifikan memediasi pengaruhleverage terhadap nilai perusahaan sehingga hipotesis keenam diterima. Hasil dariuji Sobeldiperoleh koefisien sebesar 5,90999 lebih besar dari 1,96. Hasil penelitian ini sejalan dengan penelitian Astutiningrum (2017) yang menemukan bahwa profitabilitas mampu memediasi leverage terhadap nilai perusahaan.

Hasil dalam penelitian ini menunjukkanbahwa profitabilitas secara signifikan memediasi pengaruhukuran perusahaan terhadap nilai perusahaansehingga hipotesis ketujuh diterima. Hasil dari uji Sobeldiperoleh koefisien sebesar 2,82989 lebih besar dari 1,96. Hasil penelitian ini sejalan dengan penelitian Laksitaputri (2012) yang menemukan bahwa profitabilitas mampumemediasi pengaruh ukuran perusahaan terhadap nilai perusahaan. 
Berdasarkan hasil analisis yang telah dilakukan diperoleh bahwa leverage berpengaruh negatif signifikan terhadap profitabilitasdan ukuran perusahaan berpengaruh positif signifikan terhadap profitabilitas. Leverage,ukuran perusahaandan profitabilitas berpengaruh positif signifikan terhadap nilai perusahaan. Profitabilitas secara signifikan memediasi pengaruh leverage terhadap nilai perusahaan serta profitabilitas secara signifikan memediasi pengaruh ukuran perusahaan terhadap nilai perusahaan.

Saran yang dapat diberikanbagi perusahaan industri barang konsumsi yaitu untuk lebih memperhatikanleverage dan ukuran perusahaan karena berpengaruh terhadap profitabilitas dan nilai perusahaan. Bagi investor yang ingin melakukan hubungan bisnis dengan perusahaan industri barang konsumsi dengan tujuan mendapatkan keuntungan berdasarkan nilai perusahaan, maka dapat dipertimbangkan faktor-faktor seperti leverage, ukuran perusahaan, dan juga profitabilitas. Bagi peneliti selanjutnya yang ingin melakukan penelitian terkait, diharapkan untuk mempertimbangkan faktor lain yang memiliki hubungan dengan leverage, ukuran perusahaan, profitabilitas, dan nilai perusahaan serta dapat melakukan penelitian pada perusahaan atau sektor yang berbeda di beberapa perusahaan besar lainnya, agar hasil penelitian dapat bervariasai yang dapat memperkaya referensi tentang leverage, ukuran perusahaan, profitabilitas, dan nilai perusahaan.

\section{REFERENSI}


Adyatmika, I Gede Putra. (2017). Pengaruh Inflasi dan Leverage Terhadap Profitabilitas dan Return Saham Pada Perusahaan Manufaktur di Bursa Efek Indonesia. Tesis. Universitas Udayana.

Ambarwati, Novi Sagita, Gede Adi Yuniarta \&Ni Kadek Sinarwati. (2015). Pengaruh Modal Kerja, Likuiditas, Aktivitas dan Ukuran Perusahaan Terhadap Profitabilitas Pada Perusahaan Manufaktur Yang Terdaftar di Bursa Efek Indonesia. e-Journal S1 Ak Universitas Pendidikan Ganesha, $3(1)$.

Andawasatya R, Rizky, Nur Khusniyah Indrawati\& Siti Aisjah. (2017). The Effect of Growth Opportunity, Profitability, Firm Size to Firm Value through Capital Structure (Study at Manufacturing Companies Listed On the Indonesian Stock Exchange). Imperial Journal of Interdisciplinary Research (IJIR), 3(2), 1887-1894.

Ardiansyah, Edo Fani. (2017). Pengaruh Leverage, Likuiditas, dan Ukuran Perusahaan Terhadap Profitabilitas Pada Perusahaan Pertambangan yang Terdaftar di Bursa Efek Indonesia. http://eprints.perbanas.ac.id/2822/1/ ARTIKEL\% 20ILMIAH.pdf. Diunduh 14 Oktober 2018.

Arindita, Galuh \&R. Djoko Sampurno. (2015). Analisis Pengaruh Struktur Modal, Profitabilitas, Kebijakan Dividen, dan Size Terhadap Nilai Perusahaan. Diponegoro Journal Ofmanagement, 4(2), 1-11.

Badruddien, Yusuf, Tieka Trikartika Gustyana, \&Andrieta Shintia Dewi. (2017). Pengaruh Good Corporate Governance, Leverage, dan Ukuran Perusahaan Terhadap Nilai Perusahaan (Studi Empiris Pada Sektor Industri Barang Konsumsi di Bursa Efek Indonesia Periode 2012-2015). e-proceeding of Management, 4(3), 2236-2243.

Astutiningrum, Dwi. (2017). Pengaruh Leverage, Ukuran Perusahaan, dan Investment Opportunity Set(IOS) Terhadap Nilai Perusahaan dengan Profitabilitas sebagai Variabel Intervening (Studi Pada Perusahaan Manufaktur Terdaftar di BEI Periode 2010-2014). http://repository.umy.ac.id/bitstream/handle/123456789/ 11396/ k. \%20 Naskah \%20publikasi.pdf?sequence=11\&isAllowed=y. Diunduh 12 Oktober 2018.

Bursa Efek Indonesia.(2018). Ringkasan Kinerja Perusahaan Industri Barang Konsumsi. http//www.idx.co.id. Diunduh 21 Juli 2108.

Chen, Li-Ju \&Shun-Yu Chen. (2011). The Influence of Profitability on Firm Value with Capital Structure as the Mediator and Firm Size and Industry as Moderators. Investment Management and Financial Innovations, 8(3), 121129. 
Cheng, Ming-Chang \&Zuwei-Ching Tzeng.(2011). The Effect of Leverage on Firm Value and How The Firm Financial Quality Influence on This Effect. World Journal of Management, 3(2), 30-53.

Cheryta, Aldea Mita, Moeljadi \& Nur Khusniyah Indrawati.(2017). The Effect of Leverage, Profitability, Information Asymmetry, Firm Size on Cash Holding and Firm Value of Manufacturing Firms Listed at Indonesian Stock Exchange. International Journal of Research in Business Studies and Management, 4(4), 21-31.

Daniel H, Wahyu \&I B. Panji Sedana. (2017). Pengaruh Ukuran Perusahaan, Suku Bunga dan Struktur Modal Terhadap Profitabilitas. E-Jurnal Manajemen Unud, 6(12), 6913-6931.

Dewi, A.A Ayu Kemara \& Ida Bagus Badjra. (2017). Pengaruh Profitabilitas, Aktiva Tidak Berwujud, Ukuran Perusahaan, dan Struktur Modal Terhadap Nilai Perusahaan. E-Jurnal Manajemen Unud, 6(4), 2161-2190.

Dewi, Made Ayu Paramita\& Made Reina Candradewi. (2018). Pengaruh Pertumbuhan Perusahaan dan Profitabilitas Terhadap Struktur Modal dan Nilai Perusahaan. E-Jurnal Manajemen Unud, 7(8), 4385-4416.

Farooq, Muhammad Azhar \&Ahsan Masood. (2016). Impact of Financial Leverage on Value of Firms: Evidence from Cement Sector of Pakistan. Research Journal of Finance and Accounting, 7(9), 73-77.

Febriana, Elia \&Djumahir. (2016). Pengaruh Struktur Modal, Kebijakan Dividen, Ukuran Perusahaan, Kepemilikan Saham Manajerial dan Profitabilitas Terhadap Nilai Perusahaan (Studi Pada Perusahaan Manufaktur yang Terdaftar di BEI Pada 2011-2013). Jurnal Ekonomi dan Binis, 21(2), 163177.

Febria, Ririind Lahmi. (2013). Pengaruh Leverage dan Ukuran Perusahaan Terhadap Profitabilitas (Studi pada Perusahaan Property dan Real Estate yang Terdaftar di Bursa Efek Indonesia). Jurnal Akuntansi, 1(3), 1-18.

Hafiyyan. (2017). Saham Sektor Konsumer Menarik Pada 2018.http://market.bisnis.com. Diakses 15 Mei 2018.

Hansen, Verawati \&Juniarti. (2014). Pengaruh Family Control, Size, dan Leverage Terhadap Profitabilitas dan Nilai Perusahaan Pada Sektor Perdagangan Jasa dan Investasi. Business Acounting Riview, 2(1), 121-130. 
Hermuningsih, Sri. (2013). Profitability, Growth Opportunity, Capital Structure and The Firm Value. Bulletin of Monetary, Economics and Banking, 16(2) 116-136.

Husnan, Suad. (2014). Manajemen Keuangan Teori dan Penerapan (Keputusan Jangka Panjang) (Edisi Keempat). Yogyakarta: BPFE.

Kartikasari, Dwi\& Marisa Merianti. (2016). The Effect of Leverage and Firm Size to Profitability of Public Manufacturing Companies in Indonesia. International Journal of Economics and Financial Issues,6(2),409-413.

Laksitaputri, Iriena Maharani. (2012). Analisis Faktor-Faktor yang Mempengaruhi Nilai Perusahaan dengan Profitabilitas sebagai Variabel Intervening (Studi Pada Perusahaan Manufaktur Yang Terdaftar Di Bursa Efek Indonesia Periode 2008-2010). Jurnal Bisnis Strategi, 21( 2), 1-17.

Musabbihan, Nelly Agustina \&Ni Ketut Purnawati.(2018). Pengaruh Profitabilitas dan Kebijakan Dividen Terhadap Nilai Perusahaan dengan Struktur Modal sebagai Pemediasi. E-Jurnal Manajemen Unud, 7(4), 1979-2009.

Nadeem, Muhammad, Rashid Ahmad, Ammar Ahmed, Naveed Ahmad, Syeda Rabia Batool \&Khalil-Ur-Rehman. (2015). The Effect Of Leverage On Financial Health Of The Firms: A Study From Cement Industry Of Pakistan. Industrial Engineering Letters, 5(5), 123-126.

Novari, Putu Mikhy \& Putu Vivi Lestari. (2016). Pengaruh Ukuran Perusahaan, Leverage, dan Profitabilitas Terhadap Nilai Perusahaan Pada Sektor Properti dan Real Estate. E-Jurnal Manajemen Unud, 5(9), 5671-5694.

Nurhayati, M. (2013). Profitabilitas, Likuiditas, dan Ukuran Perusahaan Pengaruhnya Terhadap Kebijakan Dividen dan Nilai Perusahaan Sektor Jasa. Jurnal Keuangan dan Bisnis, 5(2), 144-153.

Pramana, I G N Agung Dwi \&I Ketut Mustanda. (2016). Pengaruh Profitabilitas dan Size Terhadap Nilai Perusahaan dengan CSR sebagai Variabel Pemoderasi. E-Jurnal Manajemen Unud, 5(1), 561-594.

Prasetia, Ta'dir Eko, Perengkuan Tommy, \& Ivone S. Saerang. (2014). Struktur Modal, Ukuran Perusahaan dan Risiko Perusahaan Terhadap Nilai Perusahaan Otomotif yang Terdaftar di BEI. Jurnal EMBA, 2(2), 879-889.

Pratama,I Gusti Bagus Angga\&I Gusti Bagus Wiksuana.(2016). Pengaruh Ukuran Perusahaan dan Leverage Terhadap Nilai Perusahaan dengan Profitabilitas sebagai Variabel Mediasi. E-Jurnal Manajemen Unud, 5(2), 1338-1367. 
Purnamasari, Diah Ayu \& Astri Fitria.(2015). Pengaruh Perputaran Piutang Dan Ukuran Perusahaan Terhadap Profitabilitas Perusahaan Kimia. Jurnal Ilmu \& Riset Akuntansi, 4(8), 1-15.

Purnamasari, Endah Dewi. (2017). Analisis Pengaruh Leverage Terhadap Profitabilitas Perusahaan yang Termasuk LQ45 Agustus 2015- Januari 2016 di Bursa Efek Indonesia. Jurnal Ilmiah Global Masa Kini, 8(1), 39-45.

Putu, Ni Nyoman G Martini, Moeljadi, Djumahir \& Atim Djazuli. (2014). Factors Affecting Firms Value of Indonesia Public Manufacturing Firms. International Journal of Business and Management Invention, 3(2), 35-44.

Putra, A.A Wela Yulia \& Ida Bagus Badjra. (2015). Pengaruh Leverage, Pertumbuhan Penjualan dan Ukuran Perusahaan Terhadap Profitabilitas. EJurnal Manajemen Unud, 4(7), 2052-2067.

Rahmadani, Fitria Dewi \& Sri Mangesti Rahayu.(2017). Pengaruh Good Corporate Governance (GCG), Profitabilitas dan Leverage Terhadap Nilai Perusahaan (Studi Kasus Pada Perusahan Perbankan yang Terdaftar Pada BEI Periode 2013-2015). Jurnal Administrasi Bisnis (JAB), 52(1), 173-182.

Riduwan \& Engkos Achmad Kuncoro. (2011). Cara Menggunakan dan Memakai Analisis Jalur (Path Analysis). Cetakan Ketiga. Bandung: Alfabeta.

Rizqia, Dwita Ayu, Siti Aisjah, \& Sumiati. (2013). Effect of Managerial Ownership, Financial Leverage, Profitability, Firm Size, and Investment Opportunity on Dividend Policy and Firm Value. Research Journal of Finance and Accounting, 4(11), 120-130.

Rudangga, I Gusti Ngurah Gede \& Gede Merta Sudiartha. (2016). Pengaruh Ukuran Perusahaan, Leverage, dan Profitabilitas Terhadap Nilai Perusahaan. E-Jurnal Manajemen Unud, 5(7), 4394-4422.

Sabrin, Buyung Sarita, Dedy Takdir .S, \& Sujono.(2016). The Effect of Profitability on Firm Value in Manufacturing Company at Indonesia Stock Exchange. The International Journal Of Engineering And Science (IJES), 5(10), 81-89.

Setiadewi, Kadek Ayu Yogamurti \& Ida Bgs. Anom Purbawangsa. (2015). Pengaruh Ukuran Perusahaan dan Leverage Terhadap Profitabilitas dan Nilai Perusahaan. E-Jurnal Manajemen Unud, 4(2), 596-609.

Setiadharma S \& Machali M. (2017). The Effect of Aset Structure and Firm Size on Firm Value with Capital Structure as Intervening Variable. Journal of Business \& Financial Affairs, 6(4), 1-5. 
Setiawati, Loh Wenny \& Melliana Lim.(2018). Analisis Pengaruh Profitabilitas, Ukuran Perusahaan, Leverage dan Pengungkapan Sosial Terhadap Nilai Perusahaan Pada Perusahaan Manufaktur yang Terdaftar di Bursa Efek Indonesia Periode 2011-2015. Jurnal Akuntansi, 12(1), 29-57.

Sucuahi, William \& Jay Mark Cambarihan. (2016). Influence of Profitability to the Firm Value of Diversified Companies in the Philippines. Accounting and Finance Research, 5(2), 149-153.

Sudiani, Ni Kadek Ayu \& Ni Putu Ayu Darmayanti. (2016). Pengaruh Profitabilitas, Likuiditas, Pertumbuhan dan Investment Oppurtunity Terhadap Nilai Perusahaan Sektor Industri Barang Konsumsi di Bursa Efek Indonesia. E-Jurnal Manajemen Unud, 5(7), 4545-4547.

Suprayitno, Dede.(2017). Sektor-Sektor Saham yang Siap Bersinar di 2018.www.investasi.kontan.co.id. Diakses tanggal 17 Maret 2018.

Suwardika, I Nyoman Agus \& I Ketut Mustanda. (2017). Pengaruh Leverage, Ukuran Perusahaan, Pertumbuhan Perusahaan, dan Profitabilitas Terhadap Nilai Perusahaan Pada Perusahaan Properti yang Terdaftar di BEI. E-Jurnal Manajemen Unud, 6(3), 1248-1277.

Ulum, Achmad Saiful. (2015). The Influence Of Profitability and Capital Structure On Firm Value (Study on Manufacturing Industries Listed at Indonesia Stock Exchange for Periode 2008-2012). Media Mahardhika, 14(1), 79-97.

Utama, Made Suyana.(2014). Buku Ajar Aplikasi Analisis Kuantitatif. Denpasar: Fakultas Ekonomi dan Bisnis Universitas Udayana.

Wiagustini, Ni Luh Putu. (2014). Dasar-dasar Manajemen Keuangan. Cetakan Pertama. Denpasar: Udayana University Press.

Winarto, Jacinta. (2015). The Determinants of Manufacturer Firm Value in Indonesia Stock Exchange. International Journal of Information, Business and Management, 7(4), 323-349. 